\title{
COMMENT
}

\section{A semi-scholarly medley?}

In July this year we received a letter from Ruth Wajnryb, who looks after the training of teachers of English at the Institute of Languages at the University of New South Wales. In it she notes that $E T$ is 'unusual':

'I refer here to the informative-instructive element as well as to the level of entertainment and fun. There is no doubt that it is a serious journal. Yet it manages to be serious without being deadly or boring; and it caters for a certain passion for words that many people fall victim to.'

Manfred Görlach is Professor of English at the University of Köln in West Germany. Regular readers of ET will be familiar with his name, through references to his work and the publications he edits: the monograph series Varieties of English Around the World and the journal English World-Wide. In the summer issue of that journal $(E W W 9: 1,1988)$ he has written a review entitled, 'English as a world language - the state of the art'. In it he includes a short statement about ET:

'English Today was started in 1985, amazingly enough by the eminently respectable Cambridge University Press, to deal with various questions of ELT, but also with varieties and the lexicography, history and sociolinguistics of English, and has since provided a medley of semi-scholarly information combined with more journalistic presentations of material.'

Such comments as 'unusual' and 'amazingly enough' suggest that it has proved by no means easy for the academic world to categorize $E T$. They are also testimony to the extent to which reporting on English has in the past been divided into the 'serious' and the rest. Professor Görlach's use of 'semischolarly' is ambiguous: it could mean that some parts of the magazine are scholarly and some are not, or that ET's content is never closer than halfway to scholarship. It is also worth pointing out that the review was never intended as a vehicle primarily for ELT (British English language teaching overseas). The noun 'medley' does, however, seem appropriate. The Collins English Dictionary (1986) notes that a medley has 'various tunes arranged as a continuous whole'. That sounds like English, only one of whose many tunes is played in the groves of academe.

Tom McArthur

The editorial policy of English Today is to provide a focus or forum for all sorts of news and opınion from around the world. The points of view of individual writers are as a consequence their own, and do not reflect the opinion of the editonal board. In addition, wherever feasible, ET leaves unchanged the orthography (normally British or American) and the usage of individual contributors, although the editorial style of the magazıne itself is that of Cambridge University Press. 